UDC 656.2

N.Y.Shramenko ${ }^{1}$, Dr. Sc. (Tech.), Prof., orcid.org/0000-0003-4101-433X, V.O. Shramenko ${ }^{2}$
DOI: $10.29202 /$ nvngu/2018-5/15

1 - Kharkiv National Technical University of Agriculture, Petro Vasilenko, Kharkiv, Ukraine, e-mail: nshramenko@ gmail.com

2 - V.N. Karazin Kharkiv National University, Kharkiv, Ukraine, e-mail: shramenko.vlad@gmail.com

\title{
MATHEMATICAL MODEL OF THE LOGISTICS CHAIN FOR THE DELIVERY OF BULK CARGO BY RAIL TRANSPORT
}

Purpose. Development of a mathematical model for the functioning of the production and transport chain (PTC) of bulk cargo delivery by routes on the basis of a logistics approach.

Methodology. The formation of a model for the functioning of the production and transport chain for the delivery of bulk cargo by rail transport is based on the analytical method of research, taking into account the principles of logistics and system analysis.

Findings. Costs of individual links of the PTC for the delivery of ore cargoes by routes are formalized: the costs of loading, storage at the consigner's depot, transportation and storage of the consignee's cargo prior to its entering the production. A mathematical model of the functioning of the PTC of bulk cargo delivery by routes is developed. The optimized technological parameters related to the operation of the whole PTC are justified: the size of the cargo consignment, the technical equipment of the freight fronts, the delivery interval.

Originality. A mathematical model of the functioning of the PTC of bulk cargo delivery by railway routes is developed, based on the system approach and the principles of logistics, taking into account the interaction of production, transport and consumption.

Practical value. The developed mathematical model of the functioning of the production and transport chain of bulk cargo delivery allows modeling the process of cargo delivery from the mineral resource extraction sites and selecting the rational parameters of the rolling stock as well as loading and unloading mechanisms, their quantitative indicators; time and quantity parameters of the freight flow, depending on the values of the price and technological parameters. The model allows solving a wide range of tasks: those of suppliers and consumers in the independent formation of the supply chain; railway transport associated with the planning and management of operational activities of stations, and the choice of vehicle resources.

Keywords: logistics chain, transportation routing, sender routes, bulk cargo, iron ore, production and transport system, mathematical model

Introduction. With the increasing complexity of the links between the participants of the market process, the requirements for productivity and the quality of the work of rail transport are being increased [1].

Since large human and material resources are involved in the transport and production sector, including the rolling stock, technological equipment, loading and unloading machines, warehouses with significant capital investments, there is a need to increase the efficiency of using the equipment of production and transportation systems in order to reduce the total costs for processing carload flows $[2,3]$.

Currently, more than $70 \%$ of the transportation load is made up of the ore-and-metallurgical cycle, energy carriers, mineral building materials and petroleum products, which are characterized by a high concentration of production and stability of material flows.

One of the most important ways to improve the system of wagon flows management is forwarding routing, which ensures a faster delivery of goods to consumers, more efficient use of shunting means, reduction of idle time of wagons at technical stations, along the way.

Analysis of the recent research and publications. Enterprises dealing with the extraction of metallurgical raw materials and concentrating complexes for its primary

(C) Shramenko N. Y., Shramenko V. O., 2018 processing can be attributed to complex production systems [4]. They are characterized by geographical disconnection of individual production facilities of an enterprise, which are interconnected by transport [5].

Depending on the structure of production and transport systems, the type of cargo, the type of transport, the nature of the technological processes of industrial enterprises, the logistics chains have their topological, structural, and technological features in the distribution and transportation of homogeneous bulk goods or diversified products [6-9].

Among the bulk goods transported by the railways of Ukraine, iron and manganese ore makes up $19.1 \%$ (2017) of the total volume of transport. The most pressing problems associated with the transportation of bulk cargo are: inefficiency of using the car fleet; delay of the rolling stock by the consignor (consignee); untimely provision of shippers with empty wagons to the extent required; imperfect tariff policy; economic contradictions between the interests of railways, consignors and operators-owners of freight cars [10].

When organizing bulk shipments, the principle of "just-in-time" logistics is used, which is ensured by the synchronization of the work of transport and production.

With all the differences in mathematical models describing the market processes, they share the common 
goal of determining the best behavior strategy of the subject (both the carrier and the customer) on the transport products market in terms of the economic content, structure, objectives and methodological approaches $[11,12]$.

The organizational forms and economic methods of integrated traffic management are designed to minimize the total costs at all stages of storage and transportation of cargo, which causes a synergistic effect $[13,14]$. This is to no small degree facilitated by the routing of cargo transportation from loading sites [15].

At the same time, through the reduction of the cost of transportation, it is advisable to develop a system of discounts to the tariff for the transportation of goods by sender routes [16]. As a result of the technical and economic analysis of the influence caused by the routing of dispatched carload flows on the operation of common and non-common use stations forming the routes, a methodology for estimating the amount of the reduction factor to the tariff for the transportation of goods by sender routes has been proposed [17].

A study conducted on the example of JSC "Metallurgical Combine "Zaporizhstal" [18] indicates that the volume of raw materials delivered to the ore yard of the enterprise can fluctuate significantly during the day. There is no definite regularity in the volumes of supplies of raw materials during the day, month or year. At the same time, $45 \%$ of the working time of the technological equipment (car loaders) is idle due to the lack of cargo, which indicates a low organization of work with suppliers on planning the supply of raw materials to a metallurgical enterprise.

One of the requirements of consignors is timely information on the availability of empty wagons and the expected time of their delivery for performing cargo operations. To solve the problem of timely provision of the rolling stock with loading resources by carriers-owners, a model on the example of the traveling salesman problem is proposed [19].

To increase the productivity of the fleet of freight cars in the organization of carloads with bulk cargoes [20], an optimization model for the entire process of hauling cars belonging to different owners was proposed. At the same time, the given model predominantly takes into account the interests of the railroad (improving the use of basic funds and increasing the profitability of railways) and does not involve the interaction of all participants in the organization of the delivery of bulk goods.

The inconsistency of the interests of supply, consumption and transport subjects led to the fact that in most cases, the supplier enterprises and consumers built additional storage areas larger in size than optimally necessary, formed technological routes of a size different from the optimal one, equipped the loading and unloading fronts with means of greater productivity than the optimal ones for respective productions.

Therefore, an important problem is the improvement of the route methods for the transportation of bulk cargo by selecting the optimal technological parameters for the rational use of technological equipment of metallurgical enterprises and vehicles that supply raw materials.
Objectives of the article. The aim of the study is to develop a mathematical model for the operation of the production and transport chain to deliver the bulk cargo by routes on the basis of a logistics approach. Objectives of the study are:

- to form a logistics chain for the delivery of iron ore by wagons from the extraction sites;

- to formalize the costs of individual links in the production and transport chain for the delivery of ore cargo routes;

- to form a mathematical model for the functioning of the production and transport chain of ore cargo delivery by routes;

- to justify the optimized technological parameters of the production and transport chain for the delivery of ore cargo by routes.

Methods.The development of a model for the operation of the production and transport chain to deliver the ore cargo by rail is based on the analytical method of research, taking into account the principles of logistics and system analysis.

Explanation of scientific results. In connection with the fact that the "just in time" delivery must be carried out with minimal costs of labor, material and financial resources, while constructing a logistics channel for cargo flows the principle of optimality must be fulfilled in addition to the system approach.

Therefore, the technological and technical parameters of the given system should be optimized. These parameters include:

- the level of stocks in warehouses of enterprises;

- the size of the consignment;

- duration of the production cycle of an enterprise;

- the capacity of technical equipment of cargo fronts, warehouses, and others.

The production and transport logistics chains (PTCs) at the micro level include subsystems such as: production, transport, marketing and distribution, consumption.

The structure of the objective function depends on the technical and technological structure of the PTC, the availability of particular elements, as well as the economic and technological parameters.

The structure of the logistics chain is considered in the transit form of supply and delivery of iron ore, when this delivery is carried out by technological routes.

The ways of ore loading at the production points are analyzed: bunker, semi-bunker, direct loading from current production. The method of direct loading from current production is adopted for research.

The structure of the channels of cargo flows, providing for the determinism of technological processes, strict synchronization of transport operation and the enterprise shipping its products, precise delivery time and the quantity of products are analyzed.

Thus, during the shipment of mineral resources into railway wagons, the cargo is continuously supplied to the wagons during the current extraction, thereby providing a synchronous mode of operation for the production of products and their loading into wagons. Accumulation of cargo on the route is carried out directly in wagons. 
For the selection of rational technological parameters of the logistic chain of iron ore delivery, it is proposed to form the objective function expressing the specific costs of manufacturing, storing, transporting and consuming finished products when the goods are delivered "just in time" and taking into account the costs of all participants of the technological process: production, transport and consumption.

Taking into account the above features, the objective function $R\left(m, q_{\text {ship }}\right)$ is formalized by sequential consideration of individual components of costs. The main components of these costs are as follows:

- costs associated with the use of the car when performing cargo operations at the loading point $R_{\text {use }}$;

- costs related to the idle time of wagons waiting to be delivered to the freight front of the sender $R_{i t}^{o}$;

- costs for the supply and removing of wagons at the point of departure $R_{s r}^{o}$;

- the cost of moving the goods to the point of delivery $R_{\text {tar }}$;

- the cost of storing the goods until the moment they enter production $R_{s g}$.

Parameters, whose values are associated with all components of the objective function serve as optimized ones.

In view of the above costs, the expression of the objective function can be written as follows

$$
R=R_{u s e}+R_{i t}^{o}+R_{s r}^{o}+R_{t a r}+R_{s g} \rightarrow \min .
$$

It should be noted that each of the components of the objective function (1) depends, in turn, on the value of the consignment shipment $m$. At a certain value $m=$ $=m_{\text {opt }}$, the reduced costs associated with the operation of the PTC are minimal $R_{\min }$. This value of the consignment shipment (mass of the technological route) is optimal.

In the study, there is considered a situation when at the contiguous station the route is formed by one loading point. In this case, the idle time of the rolling stock increases under the accumulation in anticipation of delivery and the increase in the rolling stock idle time under loading is possible, due to the fact that the technical equipment of the cargo front is limited, and its increase requires additional capital investments.

The process of forming a sender route in the ore mining area is considered. Ore extraction is carried out by open-pit mining, with the need for continuous supply of wagons, since the ore to be mined can only be loaded into wagons, and there are no containers for its accumulation. For continuous loading of ore in quarries, a nonreducible reserve of gondola cars must be provided, which are used as "warehouses on wheels".

The demand is interpreted in two ways: on the production side it is an order for empty cars, and for the railway - an application for shipment of finished products. Since the demand is a fixed quantity, as a rule, there are costs for the storage of ore at the quarry due to a shortage in the stock of wagons.

At the enterprises, the cost function of the supplier for the execution of the order represents the total operat- ing costs expressed in two main components: the costs associated with the idle time of the wagons under freight operations and the content of the LUM (depreciation and current repairs).

$$
R_{\text {use }}=C_{\text {in }}\left(\sum_{b} \frac{m q_{s t}}{q_{\text {load } \mathrm{b}}}+t_{s r}\right) \cdot m+\frac{\sum_{b} \frac{q_{\text {load } \mathrm{b}}}{q_{0 b}} A_{b}^{L U M} K_{M b} m}{\sum_{j} h_{j} m_{j}},
$$

where $C_{i n}$ is the cost of using the car depending on the number of hours of idle time of the car under loading $t_{l}$, $\mathrm{UAH} / \mathrm{h} ; m$ is the composition of the sender's route, wagon; $q_{s t}$ is the average static load of the car, $t ; t_{s r}$ is the time for the production of all operations for supply and removing of wagons, $h ; h_{j}$ is the number of routes of the $\mathrm{j}^{\text {th }}$ destination for the planned period (month); $q_{\text {load }}$ is the total productivity of the LUM of type $b$ at the loading point, $\mathrm{t} / \mathrm{h} ; q_{o b}$ is the productivity of one LUM of type $b, \mathrm{t} / \mathrm{h}$; $A_{b}^{L U M}$ is annual deductions for amortization of one LUM, \%; $K_{M b}$ is the cost of one LUM of type b, UAH; $m_{j}$ is composition of the route of the $\mathrm{j}^{\text {th }}$ destination, wagon.

The storage costs of the finished product at the sender with the continuous accumulation process depend on the number of wagons on the sender route $m$ for each route being formed, the cargo front productivity $q_{\text {load }}$ and the cost of constructing the additional warehouse area of the $K_{\text {wear }}$

$$
R_{i t}^{o}=\frac{A K_{\text {wear }}}{365 \cdot 24} \sum_{b} \frac{q_{s t}}{q_{\text {load } b}} m,
$$

where $q_{\text {load }}$ is the hourly capacity of the loading point, $\mathrm{t} / \mathrm{h} ; A$ is the annual depreciation, attributable to the additional warehouse area, $\% ; K_{\text {wear }}$ is the cost of building an additional warehouse area, UAH; 365 is the number of days in a year; 24 is the number of hours in a day.

When using railway industrial transport at enterprises that have their own access roads, the cost function includes the costs associated with idle cars waiting for delivery (assuming that empty cars arrive at the junction station evenly) and the mileage of the shunting locomotive.

$$
R_{s r}^{o}=C_{i n} t_{a c c} m+C_{1} t_{s r},
$$

where $t_{a c c}$ is the time of accumulation of wagons for delivery to the cargo front of the enterprise from the contiguous station; $C_{1}$ is the cost of one feed to the freight front, $\mathrm{UAH} / \mathrm{h}$.

The costs associated with transportation by the main rail without taking into account the cost of the initial operations, as they were taken into account at the previous stage, depend on the size of the transport lot $m$, the distance of transportation $l$ and the computed value of the competitive tariff for rail transport

$$
R_{t a r}=T_{a r}(l) \cdot m,
$$

where $T_{a r}$ is the tariff for the transportation of ore by wagon shipments to the distance $l, \mathrm{UAH} /$ wag; $l$ is the distance of transportation, $\mathrm{km}$.

The cost of storing the goods at the consignee until the moment of its entering into production 


$$
R_{s g}=C_{u s e} \frac{m q_{s t}}{2 Q_{p}} \cdot m,
$$

where $C_{\text {use }}$ is the rate of payment for using a car during the day, $\mathrm{UAH} / \mathrm{day} ; Q_{p}$ is the cargo front performance at the consignee, $\mathrm{t} /$ day.

It should be noted that the functions of each stage $R_{0}$, $R_{1}, \ldots, R_{4}$ were obtained on the basis of a detailed analysis of the technology of the relevant parts of the PTC.

Analyzing the research studies carried out and the obtained relations $(2-6)$, the mathematical model of the entire PTC functioning for ore cargoes delivery is offered

$$
\begin{gathered}
R\left(m, q_{\text {load }}\right)=\left[C_{\text {in }}\left(\sum_{b} \frac{m q_{s t}}{q_{\text {load } b}}+t_{s r}\right) \cdot m+\right. \\
+\frac{\sum_{b} \frac{q_{\text {load } b}}{q_{0 b}} A_{b}^{L U M} K_{M b} m}{\sum_{j} h_{j} m_{j}}+ \\
+\frac{A K_{\text {wear }}}{365 \cdot 24} \sum_{b} \frac{q_{s t}}{q_{\text {load } b}} m+C_{\text {in }} t_{\text {acc }} m+C_{1} t_{\text {sr }}+ \\
\left.+T_{a r}(l) \cdot m+C_{\text {use }} \frac{m q_{s t}}{2 Q_{n}} \cdot m\right] \times \frac{1}{m} \rightarrow \min .
\end{gathered}
$$

The values of the parameters $m^{\prime}$, and $q_{\text {load }}^{\prime}$, which minimize the objective function (7), expressing the total current costs associated with the operation of the entire PTC, are optimal for this PTC.

Moreover, the functional (7) has a number of limitations:

1. The restriction caused by the physical meaning of the quantities

$$
\left(m^{\prime}, q_{\text {load }}^{\prime}\right) \geq 0 \text {. }
$$

2. Weight limitation of the gross train

$$
m q_{s t} \leq Q_{b r}
$$

3. Compliance with the "just-in-time" requirement, when the maximum delivery interval for a consignment should not exceed the value $I_{0}$ stipulated by the contract between the manufacturer and the consumer

$$
\frac{m q_{s t}}{Q_{n}} \leq I_{0} .
$$

4. Limitation on the capacity of railways $\tau$ at the junction station

$$
m \leq \tau .
$$

Given the specifics of the technology of mining operations, if the delivery interval for finished products (ore) to the metallurgical plants is met, the condition (10), the delivery time of the order will be also fulfilled. Otherwise, both conditions will not be met. Moreover, for the metallurgical plants, which are the consumers of this type of cargo, characterized by continuous technology, the primary importance is the interval of supply of raw materials.
Given these features, the restriction on the delivery date in further calculations is not taken into account.

By minimizing the obtained integral index $R$, the values of the parameters $m$ and $q$ are determined. The values of $m$, and $q_{\text {load }}$ determine the main parameters associated with the operation of the entire PTC, which are optimal for this PTC:

- raw material delivery interval $n$

$$
n=\frac{m q_{s t}}{Q_{n}} ;
$$

- the required number of $b$-type loading and unloading machines

$$
B_{b}=\frac{q_{\text {load } b}}{q_{0 b}} .
$$

Thus, the developed mathematical model for optimizing the parameters of the logistics chain of delivery of ore cargo is based on the interaction of production, transport and consumption.

Conclusions. The conducted research made it possible to obtain the following results:

- a logistics chain for the delivery of iron ore by wagons has been formed, in which four technological elements have been integrated in order to maximize the interconnection of production and transportation processes: storage and preparation of iron ore at the extraction sites; operations for the formation of trains with iron ore; transportation of iron ore; warehousing of insurance and operational ore reserves at the consumer. The approach to the construction of a PTC is universal and, depending on the task, the number of links involved in the supply chain of the cargo can vary;

- the costs of individual links in the production and transport chain for the delivery of ore cargo are formalized by routes: the costs of loading, storage at the sender's, transportation and storage of the consignee's cargo prior to its entering the production;

- a mathematical model for the functioning of the entire PTC was developed, based on the system approach and the principles of logistics. The model is universal, open and can be expanded by the introduction of additional stages at different levels of the PTC to accommodate a greater number of factors affecting the final result.

The proposed model allows solving a wide range of tasks:

a) those of suppliers' and consumers' with an independent choice of material movement options, namely: parameters of the rolling stock and the loading and unloading mechanisms, their quantitative indicators; time and quantity parameters of the cargo flow;

b) those of the railway transport associated with the planning and management of operational activities of stations, and the choice of vehicle resources.

The optimized technological parameters associated with the operation of the entire PTC are justified: the size of the cargo consignment, the technical equipment of the freight fronts, and the delivery interval.

Prospective directions of research include determination of optimal values of technological parameters as 
a result of modeling and development of a single technological schedule for interaction between the production, transport and consumption.

\section{References.}

1. Matsiuk, V. I., 2017. A study of the technological reliability of railway stations by an example of transit trains processing. Easterneuropean Journal of Enterprise Technologies, 1(3(85)), pp. 18-24. DOI: 10.15587/17294061.2017.91074.

2. Shramenko, N. Y., 2015. Effect of process-dependent parameters of the handling-and-storage facility operation on the cargo handling cost. EasternEuropean Journal of Enterprise Technologies, 5(3(77)), pp. 43-47. DOI: 10.15587/1729-4061.2015.51396.

3. Okorokov, A. M., 2014. Strategic management of transport cargo complex. Science and Transport Progress: Bulletin of Dnipropetrovsk National University of Railway Transport after academician V. Lazaryan, 4(52), pp. 101-110.

4. Besta, P., Mikoláš, M., Zapletal, F., Haverland, J. and Hendrych, M., 2013. Monitoring the quality of suppliers of input raw materials in metallurgical production [pdf]. Available at: <http://metal2014.tanger.cz/files/proceedings/12/reports/1662.pdf > [Accessed 17 April 2017].

5. Turpak, S., Taran, I., Fomin, O. and Tretyak, O., 2018. Logistics technology to deliver raw material for metallurgical production. Naukovyi Visnyk Natsionalnoho Hirnychoho Universytetu, 1, pp. 162-169. DOI: 10.29202/nvngu/2018-1/3.

6. Logutiva, T. and Poltoratskiy, M., 2015. Modern state of a transport infrastructure of Ukraine. Theoretical and Practical Aspects of Economics and Intellectual Property, 2(2(12)), pp. 8-14.

7. Nagorniy, E. V., Muzylyov, D.A. and Cherepaha, A. S., 2012. Perfection of the transportation technology for the consumer goods in the cities with the use of the logistic principles. Eastern-European Journal of Enterprise Technologies [onlne], 3(2(57)), pp. 44-46. Available at: <http://journals.uran.ua/eejet/article/ view/3981/3648> [Accessed 17 June 2018].

8. Muzylyov, D. O. and Stebakov, O. E., 2014. Method of determination of the number of units of machinery for the harvesting complex for different grain delivery technologies. Technical service of agroindustrial, forestry and transport complexes, 2, pp. 128-140.

9. Okorokov, A. M., 2014. Research and evaluation of logostic systems of raw material delivery to the enterprise of the east of Ukraine. Coll. of sci. works of DSURT after academician V. Lazaryan, 8, pp. 120-126.

10. Obukhova, A.L., Shevelyova, M.S. and Steshenko, N. O., 2015. Analysis of the main problems in transporting bulk cargoes in wagons. Coll. of sci. works UkrSURT, 152, pp. 45-49.

11. Shramenko, N. Y., 2017. The methodological aspect of the study feasibility of intermodal technology of cargo delivery in international traffic. Naukovyi Visnyk Natsionalnoho Hirnychoho Universytetu, 4(160), pp. 145-150.

12. Shramenko, N. Y., 2017. Evaluation of the effectiveness of piggyback traffic in the context of creating transport and logistics clusters. Naukovyi Visnyk Natsionalnoho Hirnychoho Universytetu, 6(162), pp. 151-155.
13. Shramenko, N.Y., 2016. Methodology for evaluation of synergy effect in terminal cargo delivery system. Actual Problems of Economics, 8(182), pp. 439-444.

14. Lenort, R. and Feliks, J., 2013. Production logistics concepts and systems in metallurgical companies [pdf]. Available at: <http://metal2014.tanger.cz/files/proceedings/12/reports/1662.pdf $>$ [Accessed 17 April 2017].

15. Kozachenko, D. N., 2013. Problems of stimulation of sender routing in railway transport. Bulletin of the Eastern European National University after V. Dal., 3(192), pp. 207-211.

16. Verlan, A. I., 2013. Perfection of methods for stimulating sender routing on railway transport. Science and Transport Progress: Bulletin of Dnipropetrovsk National University of Railway Transport after academician V. Lazaryan, 49, pp. 75-85.

17. Verlan, A. I., Pinchuk, E. P. and Zhuravel, I. L., 2014. Improving the methods of technical and economic assessment of the efficiency of cargo transportation by sender routes. Coll. of sci. works of DSURT after academician V.Lazaryan, 7, pp. 10-14.

18. Mynyailo, N.A., 2014. Analysis of the work of the car dumper at the ore yard of the metallurgical enterprise. Metalurgiya, 1(31), pp. 13-18.

19. Kuleshov, A. V., 2013. Improve information of solving the problem of modeling traffic routing bulk. Coll. of sci. works UkrSURT, 137, pp. 122-129.

20. Lavrukhin, O.V., Baulina, H.S. and Bogomazova, H. Ye., 2015. Scientific approaches to improving the technology of operation of freight cars of all types of ownership. Informational and control systems for rail transport, 4, pp. 48-55.

\section{Математична модель логістичного ланцюга доставки масових вантажів залізничним транспортом}

\section{Н. Ю. Шраменко ${ }^{1}$, В. О. Шраменко}

1 - Харківський національний технічний університет сільського господарства імені Петра Василенка, м. Харків, Україна, e-mail: nshramenko@gmail.com 2 - Харківський національний університет імені В. Н. Каразіна, м. Харків, Україна, е-mail: shramenko.vlad@gmail. com

Мета. Розробка математичної моделі функціонування виробничо-транспорного ланцюга (ВТЛ) доставки масових вантажів маршрутами на основі логістичного підходу.

Методика. Формування моделі функціонування виробничо-транспорного ланцюга доставки масових вантажів маршрутами залізничного транспорту базується на аналітичному методі дослідження 3 урахуванням принципів логістики й системного аналізу.

Результати. Формалізовані витрати окремих ланок ВТЛ доставки рудних вантажів маршрутами: витрати з навантаження, зберігання у відправника, транспортування й зберігання вантажу в одержувача до моменту надходження його у виробництво. Розроблена математична модель функціонування 
ВТЛ доставки масових вантажів. Обгрунтовані технологічні параметри, що оптимізуються, пов'язані із функціонуванням усього ВТЛ: розмір транспортної партії вантажу, потужність технічного оснащення вантажних фронтів, інтервал поставки.

Наукова новизна. Розроблена математична модель функціонування ВТЛ доставки масових вантажів маршрутами залізничного транспорту, що заснована на системному підході та принципах логістики й враховує взаємодію виробництва, транспорту та споживання.

Практична значимість. Розроблена математична модель функціонування ВТЛ доставки масових вантажів дозволяє моделювати процес доставки вантажів з місць видобування корисних копалин i здійснювати вибір раціональних параметрів рухомого складу й вантажно-розвантажувальних механізмів, їх кількісних показників; часових і кількісних параметрів вантажопотоку в залежності від значень цінових і технологічних параметрів. Модель дозволяє вирішити широке коло завдань: постачальників і споживачів при самостійному виборі варіантів матеріалоруху; залізничного транспорту, пов'язаних із плануванням і управлінням експлуатаційною роботою станцій, вибором ресурсів транспортних засобів.

Ключові слова: логістичний ланцюг, маршрутизація перевезень, відправницькі маршрути, масові вантажі, залізна руда, виробничо-транспортна система, математична модель

\section{Математическая модель логистической цепи доставки массовых грузов железнодорожным транспортом}

\section{Н. Ю. Шраменко ${ }^{1}$, В. А. Шраменко}

1 - Харьковский национальный технический университет сельского хозяйства имени Петра Василенко, г. Харьков, Украина, e-mail: nshramenko@gmail.com

2 - Харьковский национальный университет имени В. Н. Каразина, г. Харьков, Украина, e-mail: shramenko. vlad@gmail.com

Цель. Разработка математической модели функционирования производственно-транспортной цепи (ПТЦ) доставки массовых грузов маршрутами на основе логистического подхода.
Методика. Формирование модели функционирования производственно-транспорной цепи доставки массовых грузов маршрутами железнодорожного транспорта базируется на аналитическом методе исследования с учетом принципов логистики и системного анализа.

Результаты. Формализованы затраты отдельных звеньев ПТЦ доставки рудных грузов маршрутами: затраты по погрузке, хранению у отправителя, транспортировке и хранению груза у получателя до момента поступления его в производство. Разработана математическая модель функционирования ПТЦ доставки массовых грузов. Обоснованы оптимизируемые технологические параметры, связанные с функционированием всей ПТЦ: размер транспортной партии груза, мощность технического оснащения грузовых фронтов, интервал поставки.

Научная новизна. Разработана математическая модель функционирования ПТЦ доставки массовых грузов маршрутами железнодорожного транспорта, основанная на системном подходе и принципах логистики, учитывающая взаимодействие производства, транспорта и потребления.

Практическая значимость. Разработанная математическая модель функционирования производственно-транспорной цепи доставки массовых грузов позволяет моделировать процесс доставки грузов с мест добычи полезных ископаемых и осуществлять выбор рациональных параметров подвижного состава и погрузочно-разгрузочных механизмов, их количественных показателей; временных и количественных параметров грузопотока в зависимости от значений ценовых и технологических параметров. Модель позволяет решить широкий круг задач: поставщиков и потребителей при самостоятельном выборе вариантов материалодвижения; железнодорожного транспорта, связанных с планированием и управлением эксплуатационной работы станций, выбором ресурсов транспортных средств.

Ключевые слова: логистическая цепь, маршрутизация перевозок, отправительские маршруты, массовые грузы, железная руда, производственно-транспортная система, математическая модель

Рекомендовано до публікації докт. техн. наук С.С.Альошинським. Дата надходження рукопису 08.08.17. 